\title{
SEJARAH HUBUNGAN ULAMA- UMARAK: PENGALAMAN SYEIKH AHMAD BIN MUHAMMAD ZAIN AL-PATANI (1856-1908)
}

Hasanudin bin Daud

\section{Pendahuluan}

Artikel ini berusaha menganalisis secara kritis sikap, pandangan dan gagasan ulama Patani ini yang menyentuh tentang pemerintahan, pentadbiran dan isu-isu politik yang mungkin pernah ditulis dan dibahaskan tetapi tidak secara khusus dan terfokus. Pentingnya kajian ini kerana pada peringkat awalnya dirasakan perbincangan ulamaulama Patani tentang aspek politik terbatas dan sangat kurang sehingga menimbulkan rasa ragu bahawa apakah mereka tidak prihatin atau peka dengan suasana politik di tanah air mereka pada masa itu (sekalipun mungkin berada di luar Patani). Jika benar, apakah kemungkinan sebab-sebab berlakunya demikian. Apakah mereka tidak terpengaruh dengan semangat atau roh kebangkitan dunia Islam di Timur Tengah dan India pada masa itu yang dipelopori oleh tokohtokoh seperti Jamaluddin al-Afghani, Sayyid Ahmad Khan, Muhammad Iqbal dan Muhammad Abduh. Umumnya dimaklumi bahawa pada abad ke-18, 19 dan 20 bahkan sebelum itu hampir keseluruhan dunia Islam berada di bawah belenggu pemerintahan asing. 
Apabila ditelusuri latar belakang sejarah Alam Melayu, khususnya Patani, pada masa dahulu pernah mempunyai sejarahnya yang gemilang sebagai kerajaan Melayu Islam yang berdaulat, merdeka dan berfungsi sebagai salah satu pusat perdagangan dan penyebaran Islam di Asia Tenggara. Kedaulatan dan kemerdekaan negara-negara Islam di Alam Melayu mulai hilang apabila satu persatu wilayahwilayah di rantau ini dijajah oleh Portugis, Sepanyol, Belanda, British, Siam dan Jepun. Patani mulai dijajah oleh Siam pada tahun $1785 \mathrm{M}$ dan kemudian wilayah ini secara rasmi diintegrasikan ke dalam negara kesatuan Siam pada tahun 1902M setelah melucutkan kedudukan raja Melayu Patani dengan menggantikan birokrat-birokrat Siam dari Bangkok ${ }^{1}$.

Kemunculan Syeikh Ahmad al-Patani adalah di dalam zaman peralihan. Kelahirannya tidak lagi di dalam sebuah negara merdeka sebagaimana dialami oleh Patani sebelumnya. Kehilangan kebebasan bukan sahaja di dalam bidang politik, tetapi juga dalam bidang pendidikan dan dakwah keislaman. Oleh sebab itulah, ulama-ulama terkenal Patani yang mengalami zaman kehilangan kemerdekaan, bertindak keluar dari negara Patani. Antara ulama Patani yang berhijrah ialah Syeikh Daud bin Abdullah al-Patani dan keluarganya telah berpindah ke Makkah dan bergiat menyebarkan agama Islam di sana. Kesan kehilangan kewibawaan Patani sebagai sebuah negara Melayu merdeka juga turut dialami oleh Syeikh Ahmad al-Patani².

Di antara faktor-faktor yang mendorong ulama-ulama besar Patani berhijrah ke Makkah adalah kerana Makkah bukan sahaja merupakan tempat suci bagi seluruh umat Islam, tetapi juga menjadi pusat Islam, bahkan hingga ke awal abad ke-20 ia masih menjadi pusat pendidikan Islam. Setelah Makkah dikuasai oleh pengaruh Wahabi, peranan ini kemudian berpindah ke Mesir. Selain itu, peralihan kekuasaan politik dari tangan Kerajaan Mamluk (1382-1516M) ke tangan Kerajaan Turki Uthmaniyah ${ }^{3}$, suasana di Makkah lebih terbuka kepada bersifat antarabangsa bagi umat Islam dan tidak ada sekatan bagi yang ingin menetap di sana. Oleh sebab itulah, Makkah pada masa itu bukan sahaja menjadi kiblat ibadat, tetapi juga kiblat ${ }^{4} \mathrm{keilmuan}$. Ini terbukti ianya didatangi oleh pelajar-pelajar bukan sahaja dari Alam Melayu, bahkan dari seluruh dunia Islam.

\section{Gagasannya Mengenai Politik (Siasah)}

Menanggapi kenyataan ini, berdasarkan firman Allah yang ertinya, "apa yang diperintahkan Rasul kepadamu maka terimalah ia, dan apa yang dilarang bagimu maka tinggalkanlah" ${ }^{\prime 5}$, sama seperti Syeikh Daud bin Abdullah al-Fatani, Syeikh Ahmad bin Muhammad Zain al-Patani 
mentafsirkan bahawa ayat ini meliputi seluruh aspek iaitu terdiri daripada Iman, Islam dan lhsan yang termasuk di dalamnya menyuruh berbuat baik, melarang kemungkaran, mengerjakan solat, mengeluarkan zakat, puasa bulan Ramadhan, haji dan jihad fi sabilillah menentang pencerobohan kafir di wilayah kekuasaan Islam. Beliau menambahkan bahawa orang yang tidak melakukan salah satu dari perkara yang digariskan oleh Islam adalah masih terhitung jahil (bodoh) terhadap pekerjaan agamanya, kerana pengertian Islam secara etimologi dan terminologi adalah menyerah, mengikut dan seluruh anggota harus mengamalkan semua aspek yang telah digariskan ${ }^{6}$.

Dari karya-karya dan tulisan-tulisan yang dihasilkan oleh ulama Patani tidaklah begitu banyak yang menyentuh tentang politik secara khusus. Umumnya bab-bab yang bercorak politik dan jihad mereka cantumkan dalam kitab-kitab fiqh sama seperti yang selalu dibahaskan oleh ulama-ulama fiqh terdahulu tanpa mengolah dan memperkembangkan pemikirannya secara mendalam. Tidaklah keterlaluan kalau dikatakan bahawa kebanyakan ulama-ulama Patani kurang berusaha mengaitkan dalam tulisan-tulisan berunsurkan politik mereka dengan fenomena politik tempatan semasa di Patani seperti pergolakan dan perebutan kuasa atau pengaruh antara Raja Melayu Patani dan Raja Siam atau usaha-usaha Inggeris menguasai negerinegeri Melayu seperti Kedah pada waktu itu? ${ }^{7}$. Syeikh Daud sendiri sebagai contohnya, antara tokoh terawal Patani yang mengetahui, memahami dan menghayati bahkan menghadapi dan mengalami sendiri fenomena ini kerana catatan sejarah menunjukkan tarikh kelahirannya (1740) dan usaha-usaha berterusan kerajaan Siam menguasai Patani dan akhirnya jatuh ke tangan Siam pada tahun 1785 adalah tempoh kehidupan dan penglibatan aktif beliau dalam pengkaryaannya.

Meskipun dakwaan-dakwaan seperti ini dilihat secara sepintas mungkin ada benarnya kalau memang hendak mengukur pemikiran politik mereka dalam konteks politik moden seperti tentang apakah Islam itu agama dan politik sekaligus, bentuk negara Islam, hubungan Islam-politik-negara, pemerintah, demokrasi dan lain-lainnya. Namun apabila dihalusi secara mendalam tentang situasi dan keadaan yang mempengaruhi pemikiran ulama-ulama Patani pada masa itu kemudian dibandingkan dengan ulama-ulama Alam Melayu lain yang sezaman dengan mereka, nampaknya gagasan-gagasan mereka tentang jihad dan politik sudah lebih dari cukup. Apatah lagi kalau dikaji secara mendalam pemikiran-pemikiran Syeikh Ahmad al-Patani, khususnya berkaitan dengan politik Alam Melayu, banyak usaha-usaha dan gagasan-gagasan beliau untuk membebaskan rantau ini dari beleggu 
penjajahan asing dan sekaligus menjadikan wilayah-wilayah ini sebagai negara Islam.

Ketokohan Syeikh Ahmad al-Patani tidaklah hanya terbatas kepada kefahaman biasa sebagai seorang tokoh ulama tradisional tetapi mencakupi pemikiran-pemikiran umum dan moden. W.M. Shaghir dalam membincangkan tentang keserlahan tokoh ini telah menganalisis pemikirannya tentang jatidiri Melayu, Bahasa Melayu, Patani Darussalam, Sains dan teknologi, politik, falsafah dan lain-lain lagi ${ }^{8}$.

Menyentuh politik, Syeikh Ahmad al-Patani adalah seorang ulama yang agresif bahkan dianggap sebagai pembangkit gerakan politik sebahagian besar ulama-ulama Alam Melayu di masa itu. Beliaulah yang dikatakan bertanggungjawab menanamkan semangat dinamis dan radikal kepada Haji Wan Musa bin Haji Abdush Shamad sehingga menyebabkan beliau (Haji Wan Musa) cenderung ke arah ilmu kemasyarakatan dan politik yang dilihat dari kaca mata Islam?.

Kegemaran Syeikh Ahmad al-Patani membicarakan tentang halhal yang berkaitan dengan politik menyebabkan banyak murid beliau termasuk ketiga-tiga ulama jajahan Kota Bharu seperti Tok Kenali, Haji Nik Mahmud bin Haji Nik Ismail dan termasuk Haji Wan Musa sendiri gemar membaca akhbar-akhbar mengenai perkembangan politik semasa di masa itu ${ }^{10}$.

Di Tanah Melayu pada masa itu, Syeikh Ahmad al-Patani pernah menganjurkan agar negeri-negeri seperti Kelantan, Patani dan Terengganu membentuk sebuah negara Islam yang akan dilindungi oleh Empayar Turki. Beliau mengharapkan agar negeri-negeri ini bersatu menentang penjajahan Siam. Untuk Kemboja, Syeikh Ahmad al-Patani menganjurkan supaya orang Cham di Kemboja mendirikan negaranya sendiri dan untuk tujuan ini beliau mengirim muridnya yang sangat disayanginya Haji Ahmad bin Wan Mohammad Zain ke Kemboja untuk mengajar dan selanjutnya menganjurkan supaya orangorang Cham di Kemboja datang belajar ke Patani dan Kelantan sebelum melajutkan pelajaran mereka ke Makkah ${ }^{11}$.

Secara lebih terfokus karya-karya Syeikh Ahmad al-Patani yang berkaitan dengan politik boleh diperhatikan dalam kitab-kitabnya seperti Hadigatul Azhar, Faridatul Faraid, al-Fatawa al-Fathaniyah, Basyarat al-Amilin wa Nazarat al-Ghafilin, atau catatan dan manuskripnya (alSiasah wa al-Tadbir). Meskipun semua kitab-kitab ini pembahasannya bukanlah khusus tentang politik dan pembahasannya juga tidak begitu meluas, namun ianya bolehlah dikatakan sebagai ulasan dan syarahan kepada persoalan figh dalam masalah muamalat, jenayah, ataupun kewajipan pemerintah atau wazir. Cuma terdapat satu atau dua kitab 
yang nampak pembahasannya sedikit menjurus tentang politik iaitu al-Fatawa al-Fathaniyah, di mana antara petikannya menyatakan :

"Dan manakala kita lemah daripada mendirikan sesuatu daripada hukum syara seperti rejam zina muhsan, dan takut fitnah yang memudaratkan Muslimin yang kita tiada kuas atas menolaknya, nescaya gugur daripada kita wijib mendirikan dia pada ketika itu, dan wajib atas sekelian Muslimin bersungguh-sungguh mencari jalan dengan tadbir dan siasat; belajar dan mempelajarkan akan anak-anak kita akan segala wasilah bagi mendirikan hukum syarak daripada ilmu siasat dan ilmu syarak hingga dapat mendirikan seperti barang yang iaitu zahir ${ }^{\prime \prime 12}$

Bukti bahawa Syeikh Ahmad al-Patani adalah seorang yang mengambil berat tentang politik dapat dilihat dari kupasannya mengenai disiplin ilmu ini. Menurut Syeikh Ahmad:

"ilmu siasah (politik) iaitu ilmu membaiki rakyat dengan menunjukkan mereka itu kepada jalan yang melepaskan mereka itu daripada tiap-tiap kekeruhan pada dunia dan akhirat. Dan iaitu ilmu siasah itu daripada anbiya' atas yang khawas (khusus) dan awam (umum), pada zahir dan pada batin mereka itu. Dan daripada raja-raja dan sultan-sultan (salathin) atas mereka itu pada zahir mereka itu jua. Dan daripada ulama atas khawas mereka itu pada batin mereka itu, sedang yang awam pada zahir mereka itu jua. Maka hukum ilmu itu wujub kifayah. Dan ghayahnya (sasaran, tujuan, kesudahannya) menceraikan perintahan atas jalan sebenar, memerintah mereka itu atas jalan adil dan menghalakan mereka itu kepada segala yang memberi manfaat mereka itu pada dunia mereka itu dan akhirat mereka itu. Dan memelihara kerajaan daripada segala barang yang menjatuhkan ke dalam kecederaan". ${ }^{13}$

Dalam kaitan dengan ilmu politik ini, Syeikh Ahmad al-Patani pernah merujuk kepada pendapat Aristotle yang ditulis oleh tokoh itu untuk Iskandar al-Yunani, terutamanya tentang 40 perkara sifat-sifat sebagai seorang pemimpin. Namun demikian, Syeikh Ahmad al-Patani masih mengganggap kurang lengkap sehingga beliau menambahkan 19 perkara lagi, iaitu sempurna anggota, baik budi, baik kefahaman, segera ternampak bagi tiap-tiap yang diperkatakan, bijaksana, elok ibarat, petah pada sekalian ilmu, benar pada perkataan, elok perlakuan muamalat, bersifat lembut, sediakan masa untuk perjumpaan, tidak lahap pada makanan, minuman dan perkahwinan, tidak bermain-main dalam pekerjaan, tinggi hemah, bersungguh-sungguh pada 
JURNAL SEJARAH

membangun kerajaan, cintai keadilan, benci kezaliman, mempunyai hati yang tabah dan berani, serta mengetahui sekelian muslihat ${ }^{14}$.

Berdasarkan petikan-petikan di atas, pandangan dan pemikiran politik Syeikh Ahmad al-Patani mirip ke arah radikal dan kekerasan dalam menentang musuh Islam sehingga menganjurkan doktrin jihad bagi masyarakat Islam Patani khususnya dan Alam Melayu umumnya untuk menolak dan menentang penjajah di negara masing-masing. Ini menonjolkan sikap anti- kolonialis dan penguasaan kafir seperti katakatanya " semua penjajah di kerajaan-kerajaan Melayu mesti digesa ke luar daripada negeri-negeri Melayu" ${ }^{\prime 15}$.

Gagasan-gagasan Syeikh Ahmad al-Patani tentang pembentukan negara Islam (dalam konsep khalifah Islam) hampir sama dengan pandangan Jamaluddin al-Afghani yang menganjurkan dan mempopularkan gagasan Pan-Islamisme di dunia Islam, terutama di negara Arab, India dan Turki. Hal ini dapat dilihat dari usaha-usaha beliau yang menganjurkan penyatuan negara-negara kecil Islam seperti Patani, Kelantan, Terengganu dan Kemboja menjadi negara Islam yang akan berada di bawah naungan khalifah Turki Uthmaniyah. Syeikh Ahmad al-Patani juga menginginkan terbentuknya sebuah negara Islam dengan terlaksananya undang-undang Islam sepenuhnya seperti rejam bagi penzina yang muhsan (telah kahwin). ${ }^{16}$

\section{Hubungannya Dengan Pemimpin-Pemimpin Alam Melayu}

Dalam konteks hubungan dengan pemimpin-pemimpin di Alam Melayu pada masa itu, kedudukan Syeikh Ahmad al-Patani adalah sebagai tempat rujukan. Yang dimaksudkan beliau sebagai tempat rujukan di sini ialah rujukan dalam pelbagai hal dan masalah. Ini bereri bahawa yang dirujuk kepada Syeikh Ahmad al-Patani bukan sahaja hal-hal yang berkaitan dengan masalah agama Islam, tetapi juga masalah politik, ekonomi, kebudayaan dan lain-lain lagi. Di antara pemimpin-pemimpin Alam Melayu yang selalu membuat hubungan dengan beliau ialah sultan Patani, Kelantan, Terengganu, Kedah, Johor, Riau-Lingga, Deli, Langkat (Sumatera), Pontianak dan Sambas ${ }^{17}$.

Syeikh Ahmad al-Patani sangat mengambil berat dengan perkembangan politik di Alam Melayu. Hubungan rapatnya dengan pemimpin-pemimpin Melayu sehingga pernah ketika Sultan Long Mansur hendak dilantik menjadi Sultan Kelantan pada tahun 1898, menjemput beliau untuk hadir di hari perlantikan tersebut. Titah baginda, sekiranya Syeikh Ahmad al-Patani yang dianggap sebagai 
orang tuanya itu tidak dapat hadir, beginda mohon dituliskan sebuah doa untuk dirinya. Antara kalimat doa yang penuh nasihat itu ialah :

"Bahawa Engkau sentosakan dia dan negerinya dan rakyatnya dan segala negeri Melayu dan raja-rajanya daripada segala kejahatan segala kuffar dan tipu daya mereka, dan tegahkan hai Tuhanku, daripada masuk mereka itu kepadanya, kuffar, ke negeri kelantan dan segala negeri Melayu dengan merintah padanya barang perintah ada ia.. bahkan tegahkan daripada masuk mereka itu kepadanya sama sekali..kami pohonkan, bahawa Engkau binasakan tiap-tiap kafir yang bercita-cita dan azam dengan menyakiti akan dia dahulu daripada sampai kejahatannya kepadanya dan kepada negerinya"18

Selain kalimat doa di atas, Syeikh Ahmad al-Patani turut mendoakan agar Sultan Long Mansur taat mengerjakan ibadat dan adil dalam pemerintahannya. Daripada kalimat itu dapat difahamkan bahawa Syeikh Ahmad al-Patani mempunyai sasaran dakwah dan pendidikan terhadap para raja baik untuk Sultan Long Mansur sendiri mahupun sultan-sultan lain, kerana memang tidak dapat dinafikan bahawa di antara raja-raja selain taat beribadat dan adil, ada juga yang melakukan maksiat dan kezaliman. Dalam kaitan ini, Syeikh Ahmąd al-Patani berpendapat bahawa:

"Pemerintah kafir ke atas penduduknya yang majoriti Muslim adalah suatu mala petaka dan bala yang maha besar. Tetapi dinamakan bala pula, walaupun dianggap agak kecil, adalah seorang Muslim memerintah diluar ${ }^{19}$ hukum-hukum Allah dan melakukan kezaliman yang tidak diredhai Allah"20

Dalam hubungan dengan pemikiran di atas, Syeikh Ahmad al-Patani dalam Al-Fatawa al-Fathaniyah berkata bahawa apabila kita "lemah syarak, seperti rejamkan zani muhsan dan takut fitnah yang mudaratkan Muslimin yang tiada kuasa kita atas menolakkannya, maka ketika itu gugurlah kewajipan kita melaksanakannya". Sungguhpun demikian, beliau menambahkan lagi bahawa adalah "wajib atas sekalian orang Islam bersungguh-sungguh mencarikan jalan dengan tadbir siasah, belajar dan mengajar anak-anak kita akan wasilah bagi mendirikan segala hukum syarak daripada ilmu siasah dan ilmu syarak hingga mendirikan dia seperti barang yang nyatanya" 21

Selain itu, hubungan beliau dengan sultan-sultan atau pemerintahpemerintah di Alam Melayu yang lain, juga turut terjalin dengan erat. Hal ini dapat dilihat dari tulisan-tulisan beliau kepada sultan- 
sultan tersebut. Di antaranya adalah surat kepada Sultan Zainal Abidin Terengganu yarg bertarikh $13 \mathrm{Muharram} 1323 \mathrm{H}$ yang isinya:

"gemilang cahayanya pada hari kiamat. Serta dilanjutkan zaman Duli Tuanku serta zuriat Tuanku di dalam hening kerajaan yang tiada mencampuri akan dia kadr (kekeruhan dan kekotoran) menyakiti ajanib (bangsa asing). Dan dilimpahkan "Menjadikan dia oleh Allah kebajikan yang makbul, yang amat gilang-dengan rikmat dan rahmat dan kekayaan yang ada padanya berkat yang memberi manfaat bagi agama Islam. Dan terangkat dengan dia oleh sebutan jenis Melayu"z2

Bagi Syeikh Ahmad al-Patani, ilmu siasah adalah sangat penting dalam menjaga kepentingan ketahanan siasah bangsa Melayu yang beragama Islam. Menurut beliau, "bangsa Melayu Islam itu sesekali tidak boleh diperintah oleh bangsa asing terutama yang bukan beragama Islam". ${ }^{23}$ Pendapat ini tentunya berkait rapat dengan kes beberapa daerah Alam Melayu yang semasa itu dijajah oleh bangsa Belanda, British dan Siam. Dalam hubungan ini, Syeikh Ahmad al-Patani berpendapat bahawa hanya kerajaan Turki Uthmaniyah sahaja yang berupaya membantu negeri-negeri Melayu ini membebaskan diri daripada penjajahan asing ${ }^{24}$. Salah seorang murid beliau yang beliau perkenalkan kepada kerajaan Turki untuk menangani urusan diplomatik ialah Raja Ali Kelana yang berasal dari Kerajaan Riau-Lingga. Menurut beliau, daripada keseluruhan kerajaan Melayu pada masa itu, Kerajaan RiauLinggalah yang masih mampu menampilkan cerdik pandai dalam bidang politik.

Usaha-usaha Syeikh Ahmad al-Patani yang membawa Raja Ali Kelana Riau menghubungi kerajaan Turki Uthmaniyah untuk membebaskan Alam Melayu tergendala apabila beliau meninggal dunia pada awal Januari 1908. Turki pula mulai lemah dalam perang Dunia Pertama (1914-1918). Sementara itu, dalam tahun 1911 Belanda berjaya memaksa sultan Riau-Lingga, Sultan Abdul Rahman Muazzam Syah, untuk menandatangani penyerahan Riau-lingga kepada Belanda dalam tempoh 12 jam. Sultan Abdul Rahman Muazzam Syah meminta tempoh sampai tempoh 24 jam, Sult memikirkan hal tersebut. Namun belum diri ke Singapura tanpa menurun Rahman Muazzam Syah melarikan dipaksa oleh pihak Belanda ${ }^{25}$. Berdankan tandatangannya seperti yang siasah Syeikh Ahmad al-Patani di atarkan doa dan gagasan-gagasan bahawa beliau bukan sahaja sebaji afas kita dapat membuat hipotesis tugas dakwah dan menukebagai seorang ulama yang melaksanakan siasah yang ulung dan gigih 
membebaskan tanah airnya Patani, tetapi juga termasuk negeri-negeri yang dijajah oleh Inggeris dan Belanda pada zaman itu.

\section{Wawasannya Mengenai Politik (Siasah)}

Menyedari betapa pentingnya ilmu politik (siasah) dan ilmu syara', Syeikh Ahmad al-Patani berusaha keras mensepadukan kedua-dua ilmu tersebut semasa mengajar ilmu-ilmu agama selama beliau menetap di Makkah. Tapi walau bagaimanapun, bagi beliau Islam tetap harus didahulukan daripada konsep-konsep yang lain. Hal ini dapat semak dengan jelas dari kata-katanya yang terkandung di dalam karyanya al-Siasah wa al-Tadbir yang antara lain berbunyi, "Urusan Islam adalah pertama-tama dan utama, urusan-urusan lain adalah sambil-sambil sahaja. Barangsiapa mendahulukan urusan-urusan lain daripada Islam agamanya, maka telah khianat kepada agamanya" in

Sungguhpun demikian, menurut perhatian beliau, tidak banyak anak muridnya yang berbakat dalam ilmu politik(siasah), kecuali beberapa orang sahaja. Diantaranya jalah Nik Mahmud bin Ismail (Kelantan) dan Haji Sulong Al-Fatani ${ }^{27}$. Oleh kerana Haji Sulong AlFatani ketika itu masih kanak-kanak (berumur 12 tahun ), maka ilmu siasah Syeikh Ahmad al-Patani banyak diperturunkan kepada Nik Mahmud.

Sebagai tambahan pada ilmu siasah, beliau juga mengajar Nik Mahmud ilmu tadbir. Bagi beliau, ilmu tadbir itu penting dalam memelihara agama Islam, diri, akal, nasab (keturunan), kehormatan dan harta benda. Penegasan ini beliau sebut secara jelas di dalam jumanatut Tauhid seperti antaranya menyebut " untuk peliharaan kesemuanya itu adalah dengan pemeliharaan watan (negeri). Berserta dengan tiap-tiap perbaikan adalah dengan tadbir yang baik pula". Beliau menambahkan lagi bahawa agama Islam akan terjamin kemurniannya apabila watannya diperintah oleh seorang Muslim. Menurut Syeikh Ahmad al-Patani, seseorang Muslim yang tidak bijaksana dalam menjalankan tadbir belum boleh menjamin yang enam perkara seperti yang disebutkan di atas dapat terpelihara menurut ajaran Islam yang sebenarnya. ${ }^{2 B}$

Menurut pandangan Syeikh Ahmad al-Patani lagi, seseorang yang hendak menjadi pemimpin, selain bijaksana dalam kira bicara, ciri lain yang perlu dimiliki ialah ketangkasan gerak fizikal dan pandai bermain senjata sama ada untuk menyerang ataupun mempertahankan diri. Selain itu perlu pula diisi dengan kekuatan mental berupa ilmu hikmah kerana Rasulullah dan para sahabatnya ketika menghadapi peperangan tidak pernah lupa untuk berdoa dengan pelbagai jenis 
doa $^{29}$. Nik Mahmud merupakan anak didik Sycikh Ahmad al-Patanj dalam bidang siasah dan tadbir yang sangat dibanggakan oleh beliau. Ketika Nik Mahmud berada di Mesir, beliau masih tetap mengambil berat terhadap pelajaran muridnya itu dengan menyatakan :

"Ayahanda (harap) anakanda mendapatkan 'ulum dan ma'arif di Mesir atas, kadar yang memberi manfaat bagi diri anakanda, bahkan bagi anak jenis Melayu kita barang belum mendapatkan dia oleh orang yang dahulu daripada anakanda daripada anak Kelantan. Dan mudah-mudahan anakanda meringgikan hemah pada mendapatkan barang yang sayugianya mendapatkan dia, bagi seumpama diri anakanda di dalam ini masa. Supaya terangkat dengan demikian itu oleh nama jenis Melayu berat dan terhebat dengan dia oleh kerajaannya pada segala hati ajanib (bangsa asing). Dan lertamadun dengan dia oleh siasah mereka itu sebagai tamadun yang mufakat dengan syarak" 30 .

Usaha gigih Syeikh Ahmad al-Patani yang membimbing dan memberikan penekanan kepada Nik Mahmud dalam bidang ilmu siasah tidak sia-sia kerana ternyata Nik Mahmud dikemudian hari dilantik menjadi Menteri Besar Dato' Perdana Menteri Paduka Raja Kelantan ${ }^{31}$.

Nik Mahmud dan kawan-kawannya termasuk Tuk Kenali dan Datuk Laksamana Haji Muhammad bin Muhammad Sa'id adalah kader-kader Syeikh Ahmad al-Patani yang telah banyak berjasa dalam pelbagai perkembangan di Kelantan. Melalui kcbijaksanaan mereka inilah Majlis Agama Islam dan Adat Istiadat Melayu Kelantan yang merupakan majlis agama Islam yang pertama ditubuthkan pada tahun 1915 di Tanah Melayu ketika itu. Malah hasil usaha mereka jugalah yang memungkinkan majalah Prngasoh diterbitkan pada tahun 1918, begitu juga dengan Madraseh at-Muhammadiah didirikan pada tahun yang sama ${ }^{32}$. Selain mengharapkan kejayaan Nik Mahmud, Syeikh Ahmad al-Patani juga meminta muridnya mengumpul pelbagai maklumat mengenai kegiatan penjajah Barat. Dalam salah satu suratnya kepada Nik Mahmud yang bertarikh 5 Jamadilawal 1324H beliau menulis :

"Dan ada kedengaran di Makkah bahawasa ada inggeris buat kacau pada tanah Sultan pada pihak Mesir. Dan apa-apa perkara jadi, dan di mana-mana tempat tidak ayahanda tahu. Maka ayakanda harapkan anakanda suruh Ismail kirimkan sedikit daripada jaridah (akhbar) pada kenyataan demikian iku"ws. 
Surat yang mengandungi maksud yang sama juga beliau kirimkan kepada anaknya Ihaji wan Ismail yang ketika itu juga sedang belajar bersama-sama Nik Mahmud dan Sycikh Tahir Jalaluddin di Mesir.

Selain melahirkan kader-kader untuk meneruskan perjuangannya, Syeikh Ahmad al-Palani juga menubuhkan sebuah organisasi pada tahun $1290 \mathrm{H} / 1873$, jaitu Jam'iyatul Fathaniyah. Organisasi ini berlanjutan sethingga ke hari tuanya. Di antara yang menjadi ahli organisasi ini ialah scmua ulama dan pelajar-pelajar yang berasal dari Alam Melayu yang berada di Makkah pada masa itu ${ }^{3}$.

Ada kemungkinan besar bahawa organisasi yang diasaskan oleh Syeikh Ahmad al-Patani ini merupakan yang pertama diasaskan untuk memperjuangkan umat Melayu dari penindasan-penindasan penjajah di rantau ini. Organisasi ini selain memperjuangkan untuk melestarikan khazanah-khazanah karya ulama Alam Mclayu dengan menerbitkan bahar-bahan tersebut, juga mengkaderkan pelajar-pelajar Melayu di Makkah ke arah pembebasan Alam Melayu daripada penjajahan. Hal ini terbukti dengan beberapa kali Sycikh Almad al-Patani meminta bantuan kerajaan Turki Uthmaniyah dengan cara memperkenalkan beberapa orang murid beliau kepada kerajaan Turki Uthmaniyah untuk urusan diplomatik. Diantaranya ialah Raja Ali Kelana yang berasal dari Riau. ${ }^{35}$

\section{Kupasannya Mengenai Ciri-ciri Pemimpin Yang Bajk}

Di antara ciri-ciri seorang pemimpin yang baik menurut Syeikh Ahmad al-Patani jaitu hendaklah berlemah lembut dengan rakyat, kasihan belas, menakutkan mereka daripada melakukan kezaliman dan menyatakan kepada mereka (rakyat) tentang kelebihan orang yang memerintah dengan adil. Dalam konteks ini beliau rnengutip firman Allah yang maksudnya "Sesungguhnya Allah memerintahkan supaya berlaku adil, berbuat baik, memberi hak kepada yang berhak, mencegah daripada perkara yang tidak baik (zina dan sebagainya), mungkar dan segala maksiat,mudah-mudahan menjadi pengajaran bagi kamu".36

Beliau seterusnya menyebut sebuah hadis yang maksudnya "tiaptiap kamu adalah pemimpin (memelihara), dan tiap-tiap pemimpin ditanya tentang yang dipimpinnya. Bermula raja itu yang memimpin (memelihara) dan akan ditanya tentang yang dipimpinnya (rakyat). Orang lelaki itu adalah yang memimpin ahli keluarganya dan akan ditanya tentang yang dipimpinnya (ahlinya). Orang perempuan adalah yang memimpin (memelihara) harta benda suaminya dan akan ditanya tentang tugasnya. Khadam (pekerja) adalah yang menjaga harta benda 
tuannya dan akan ditanya tentang tugasnya. Tiap-tiap kamu adalah pemimpin dan akan ditanya tentang tugasnya" 37

Berdasarkan hadis, beliau menyebut bahawa ada empat orang yang dimurkai oleh Allah, iaitu penjual yang banyak bersumpah, fakir yang sombong (takbur), orang tua yang berzina dan raja yang zalim. Masih berdasarkan hadis, beliau menyebut bahawa manusia yang paling dikasihi dan terlebih dekatnya mereka itu kepada Allah di hari kiamat ialah raja yang adil. Manakala yang sangat dibenci dan terlebih daripada Allah ialah raja yang zalim ${ }^{38}$.

Seterusnya beliau menyebut bahawa takutlah kamu akan doa orang yang kena zalim, kerana sesungguhnya orang yang kena zalim akan meminta haknya kepada Allah dan Allah tidak akan mencegah orang mempunyai hak tentang haknya. Seterusnya beliau menyebut bahawa hendaklah kamu jauhkan dari segala doa orang yang kena zalim kerana di antaranya dengan Allah tidak ada dinding. Doa orang yang kena zalim itu mustajab walaupun ia seorang yang jahat, kerana jahat itu atas dirinya. ${ }^{3}$

Menurut Syeikh Ahmad al-Patani, bahawa ada tujuh orang yang akan diberi tempat berteduh oleh Allah di bawah naungan-Nya pada hari tidak ada naungan kecuali naungan-Nya, iaitu raja yang adil, orang muda yang besar di dalam ibadat kepada Allah, orang lelakj yang bergantung hatinya dengan masjid, dua orang yang saling berkasih sayang kerana Allah; berhimpun dan bercerai kerana Allah, seorang lelaki yang diajak oleh seorang perempuan yang mempunyai kelebihan dan kecantikan, maka berkata ia bahawa aku takut kepada Allah, seorang yang bersedekah tetapi menyembunyikan (merahsiakan) sehingga tiada mengetahui oleh tangan kirinya akan barang yang disedekahkan oleh tangan kanannya dan seorang yang menyebutkan Allah dalam keadaannya seorang diri, maka mengalir air matanya."

Selain mengambil dari sumber al-Quran dan hadis tentang ciriciri seorang pemimpin yang baik, beliau juga ada menyebut di antaranya ialah seseorang pemimpin itu mesti sempurna anggotanya, baik kelakuan, cerdik, mahir dalam ilmu matematik dan ilmu sejarah, dan tidak banyak makan, minum dan kahwin." Seterus beliau menyebut bahawa sayugialah memperbaiki mu'amalah sesama kaum Musimin pada segala pekerjaan agama dan dunia. Hendaklah semua urusan itu berpedoman dengan hukum syara', mengikut apa-apa yarg telah digariskan oleh Nabi Muhammad S.A.W. Pergauljlah semua manusia dengan sebaik-baiknya akan tetapi harus ingat, sangatsangatlah utama menjauhi sesama manusia apabila akibat pergaulan itu membawa fitnah yang dicela oleh agama Islam. 


\section{Kesimpulan}

Dalam bidang pemerintahan, Syeikh Ahmad al-Patani adalah seorang ulama Melayu yang sangat mengambil berat terhadap perkembangannya dan sangat prihatin dengan perkembangan politik semasa di dunia Islam, khususnya yang berkaitan dengan Alam Melayu. Suatu hal yang menarik bahawa hampir semua murid-murid beliau menjadi ulama besar, tokoh-tokoh kenegaraan yang tercatat dalam sejarah perkembangan kemajuan keagamaan di rantau ini. Gagasan dan perjuangan beliau diteruskan dan diperjuangkan oleh rangkaian murid-murid beliau baik sebagai ulama mahupun sebagai pemimpin Negara. Selain hubungan beliau dengan raja dan pemimpinpemimpin Melayu, Syeikh Ahmad al-Patani juga mempunyai hubungan yang akrab dengan pemerintah Turki Uthmaniyah yang beliau mempunyai cita-cita untuk mewujudkan negara Islam meliputi Patani, Kelantan, dan Terengganu dan secara langsung kerajaan Islam ini berada di bawah naungan Kerajaan Turki Uthmaniyah. 


\section{Nota}

1 Surin Pitsuwan, Islam Di Mhongthai : Nnsionalisme Mrlayn Masyarakat Patani. Hasan Basari (terj.).(Jakilrta : LP3ES.1989), hlm.22 Syafie Abu Bakar, "Sumbangan Syeikh Ahmad Di Dalam Bidang Bahasa dan Sistera". (Kertas kerja Seminar Pemikiran Syeikh Ahmad bin Mohd. Zain, Kota Bharu, 11-12 Seplember 2002 ), hlm.l Menurut Hamka, pada masa itu Kerajaan Turki Uthmani menggelarkan dirinya sebagai "Fami Hima al-Haramayn al-Sharifayn. Lihal Sejarah Umat IsJam. (Kuala Lumpur : Pustaka Antara, 1965), hlm.381.

$5 \quad$ Surah Al-Hasyr, ayat 7.

5 Wan Muhammad Shaghir Abdullah, Styeikh Datd Bin Abdullah AtFathani Perulis Istam Produktif Asia Tenggara.( Solo : Ramadhani, 1987), hlm.63.

- Kamarudin Haji Salleh et al., "Isu-ìsu Politik Dalam Pemikiran Syeikh Daud Dan Syeikh Ahmad A1-Fatani : Satu Analisis", (Kertas Kerja Nadwah Ulama Nusantara I pada 19-20 Mei 2001 di Kolej Pengajian Islam, Prince of Songkla University, Pattani), hlm.8. Wan Muhd. Shaghir Abdullah, Al'Allamah Syeikh Ahmad Al-Fahani Ahli Fikir isiam Dan Dunia Melayn. (Kuala Lumpur : Khazanah Fathaniyah, 1992), hIm.53-75. Alías Muhammad, Intelegensia Melayk Kelantan.l Kota Bharu : Mohd Nawi Book Slore, 1977), hlm33. Nik Abdul Aziz Nik Hasan, Sejamh Perkentbangan Ulann Kelantan. (Kota Bharu : Pakatan Keluarga Tuan Tabal,1970), hlm. 100. Abdul Rahman Al-Ahmadi, "Pokok Pemikiran Haji Mohammad Yusuf bin Ahmad Al-Kenali (Tok Kenali)", (Kertas Kerja Persidangan Antarabangsa Tamadun Melayu ke-Il pada 15-20 Ogos 1989 di Kuala
Lumpur), hlm. 3.

" lbid., hlm. 3.

12 Wan Mohd. Shaghir Abdullah, Al-Allamah, hlm.106.

13 Syeikh Ahmad bin Muthammad Zain al-Patanj, Hadig Rayahin.Wan Muhd. Shaghir Abdullah (tanj, Hadigalul Azhar War Khazanah Fathaniyah, 1998), hlm. 194.

14 Ibid., him. 200-202. Lithat juga Wan Muhd. Shaghir Abdullah, AlSyeikh Ahmad bin Muhammad Zain Al-Fatani, Al-Siasah ara al-Tadbir
(manuskrip), him. 4. Wamarudin Haji Salleh dan Mazlan Ibrahim, lsti-isit, hlm.18. Tenggara (2). (Kuala Lumpur: Khazanah Pentikiran islan Ulama Asia

11 Wan Muhd. Shaghir Abdullah, Al-Alla Fathaniyah, 2000), hlm. 46.

18 Syeikh Alumad bin Muhammad Zain al-Patani, 110.

20 Wan Mohd. Shaghir Abdullah, "Syejkh Ahi, Al-Siasah, hlm. 3. Politik dan Riau", dalam Detun Budays, (kual tum Al-Fatani: Sultan, dan Pustaka, 1992), hlm. 51. lbid., hlm.107. 
22 Syeikh Ahmad bin Muhammad Zilin a]-P'atani, Sinsoh, hlm.5.

23 Wan Moht. Shotghir Abdtuliah, Al-Allamuh, hlm. 113.

24 Wan Mohd. Shughir Abdullah, Sifiskl Almad Af-fatami, hlm. 53.

25 Wan Mohd. Shaghir Abetullah, Wartussm, him. 50.

it Namil penubnya ialah I laji Mulhatmmad Sulong bin Flaji Abdıl Kadir. Belian acdalah cucu kepida E Iaji Kalinal Abidin bin Muhammad (Tuan Minal) penulis kitab Kushf at-l.itham. Kemasyhuran flaji Sulong bukan kerana banyak meninggalkan karya-karya se'perti ulama-ulama Patani yang lain, tetapi terletak pada kegigithan dan penglibalan beljau dalam perjuangan rakyal l'alani sekilar tahun-tahun 40-an dan 50-an. Kemalian betiau secara misteri pada bulan Ogos 1954 akibal dari tuntulan "Iujuh perkaranya" semakin menambahkan lagi kemasyhtran beliau di kalangan rakyat Palani. lbici. hlm. 52. Sycikl Ahmad bin Muhammad Zain al-Patani, Luqtaful Ajlan.( Makkah: Matbaah al-Miriyah, 1330ri), hlm. 4. Wan Mohd. Shaghir Abdullah, Al-Alamtal, hlm. 108. Yusoff Zaki Yakob, "Tok Kenali", dalam Ismail Che Daud (ed), Tokol:Tokoh Whata Somennijomg Mrdalix. (Kota Bharu: Majlis Ugama Islam dan Adat Istiadat Melayu Kelantan,1992), hlm. 201.

"Ibid., hlm. 202.

32 Wan Mohd. Shaghir Abdullah, At-Allamah, hlm. 109.

3) Wan Mohd. Shaghir Abdullah, Wawasan, hlm. 103.

s4 Ibid,, hlm. 104.

35 al-Quran, surah al-Basyarat, ayat 91.

so Syeikh Ahmad bin Muhammad Zain al-Patani, Basyanat al-Amilin wa Nazarat al-Ghofilin. (Kuala Lumpur: Khazanah Fathanyah, 1999), hlm. 91.

37 Ibid, hlm. 92.

J8 Syeikh Ahmad bin Muhammad Zain al-Patani, Basyarat, hlm. 62.

"I Ibid., hlm. 93.

40 Wan Mohd. Shaghiy Abdullah, al-Allamah, hlm. 104.

1 lbid., hlm. 105. 